\title{
Změny v uvažování o participaci žáků: zahraniční inspirace
}

\author{
Jitka Vidláková \\ Mendelova univerzita v Brně, Institut celoživotního vzdělávání, Oddělení sociálních věd
}

Redakci zasláno 9. 1. 2012 / Do tisku přijato 16. 3. 2012

\begin{abstract}
Abstrakt: Tématem příspěvku je participace žáků na životě školy. Jedná se o aktuální téma české i zahraniční pedagogiky, o němž se s různou mírou intenzity diskutuje i píše v kontextu měnících se společenských podmínek a s nimi souvisejícími proměnami současné školy, pojetí výuky a pozice žáka $v$ těchto procesech. Zabývat se budeme změnami v uvažování o participaci žáků v posledních letech, $v$ jejichž důsledku vznikly vzahraničí nové modely participace žáků. Studie nabízí konkrétněpřehled těch modelů participace žáků, v nichž jejich autoři kladou důraz na naslouchání žákům dospělými ve škole. Další část textu je věnována vymezení konceptu označovaného v zahraničí jako student voice (hlas žáků), který se objevuje v souvislosti s představenými modely. Součástí pokusu vymezit hlas žáků jsou také úvahy o vhodnosti používání spojení hlas žáků. V závěru předkládáme klíčové otázky týkající se participace žáků, jejichž teoretické i empirické uchopení u nás zatím absentuje. Studie je orientována především na výzkumníky zabývající se tímto tématem, avšak svým zaměřením přináší podněty a inspiraci i dalším odborníkům a pro školní praxi.
\end{abstract}

Klíčová slova: participace žáků na životě školy, hlas žáků, konzultování, naslouchání, žák

\section{1 Úvodem}

Otázka aktivního zapojení žáků do nejrůznějších oblastí života školy se v posledních dvou desetiletích dostala ve zvýšené míře do centra pozornosti výzkumníků i politiků. Zájem o participaci žáků přitom vychází z obecnějšího zájmu o participaci dětí a mládeže na životě společnosti. Ta je zakotvena v četných mezinárodních i českých dokumentech (Bílá kniha..., 2002; Koncepce státní politiky..., 2003; Národní program..., 2001; Revidovaná Evropská charta..., 2004). Úvahy o participaci žáků se týkají zejména vytváření podmínek pro jejich aktivní účast na výuce a dění ve škole, vytváření projektů, přístupu učitelů $\mathrm{k}$ žákům aj. K hlavním důvodům, proč se zabývat participací žáků, patří především požadavek demokratického uspořádání a fungování škol a současně naplňování práv dětí a mládeže. V posledním desetiletí je 
také stále více zdůrazňována participace žáků a její potenciál pro rozvoj škol a efektivitu jejich práce. Participace žáků současně představuje jednu z forem výchovy k občanství a aktivní účasti mladých lidí v otevřené společnosti.

Z hlediska naplňování hlavních cílů školního vzdělávání je důležité, aby se žáci mohli aktivně zapojovat zejména do procesu výuky. V mnoha současných výzkumech se ukazuje, že čím více žáci participují na průběhu výuky, tím lepších výsledků dosahují (Efektivní učení..., 2005). V tomto kontextu je zdůrazňován především potenciál participace pro osobnostně sociální rozvoj žáků, schopnost reflexe svého učení, schopnost pojmenovat, co z jejich pohledu učení podporuje/nepodporuje větší zájem o učení aj. Výzkumy potvrzují i význam sociální participace (účast na sociálním dění) a vzájemné spolupráce žáků, které podporují jejich učení a školní výsledky (Efektivní učení..., 2005).

Zejména $\mathrm{v}$ průběhu 90 . let 20 . století vznikla $\mathrm{v}$ zahraničí řada modelů participace žáků, které ale $\mathrm{v}$ poslední dekádě procházejí v důsledku změn v uvažování o participaci žáků svojí revizí. Výsledkem těchto změn byl mimo jiné vznik nového konceptu, který bývá v zahraničí označován jako pupil/ student voice/s, v českém překladu hlas/y žákủ. Následně se v odborných textech začaly objevovat nové modely, $\mathrm{v}$ nichž autoři už nekladou důraz primárně na úroveň a míru participace žáků, jako tomu bylo doposud (např. Hart, 1997; Treseder, 1997), ale zohledňují také to, zda dospělí naslouchají žákům a jejich hlasy při vzájemné spolupráci a spolurozhodování zohledňují (Fielding, 2001; Holdsworth, 2000; Mitra, 2007). ${ }^{1}$ Tyto změny v uvažování o participaci žáků, ale zatím nejsou dostatečně reflektovány $\mathrm{v}$ české pedagogické teorii ani výzkumu.

Cílem příspěvku je nejprve představit modely participace žáků vzniklé jako reakce na zvýšený zájem výzkumníků o hlasy žáků. Spojení hlas žáků se v české pedagogice zatím příliš neobjevuje, proto je další část textu věnována popisu tří typických způsobů vymezování konceptu hlas žáků, s nimiž se lze setkat v zahraniční odborné literatuře. Součástí představení tohoto konceptu jsou také úvahy o tom, zda je používání spojení hlas žáků vůbec vhodné v souvislosti s jejich participací na životě školy. V další části příspěvku jsou

V souvislosti s tímto posunem v uvažování nad participací žáků se u zahraničních autorů můžeme setkat i se slovním spojením pupil/student voice activities na místech, kde by ještě v 90. letech 20. století běžně použili spojení participace žáků (např. Fielding, 2004a; Flutter \& Rudduck, 2004; Holdsworth, 2000). 
popsány některé problémy, které se mohou objevit při uplatňování hlasu žáků v prostředí školy. V závěru studie jsou identifikovány hlavní otázky týkající se participace žáků, jejichž zodpovězení považujeme za podstatné pro rozvoj tématu v rovině teorie, výzkumu i z hlediska školní praxe.

\section{Nové modely participace žáků}

V literatuře i samotné školní praxi se tak dnes setkáváme s množstvím rozmanitých modelů participace žáků. Uvedené platí především o literatuře zahraniční, nebot' zde je tradice zájmu o tuto problematiku mnohem delší. Vedle dnes již přijímaných modelů participace žáků se v literatuře nedávno začaly objevovat nové modely participace zohledňující hlasy žáků. $\mathrm{V}$ původních modelech byly u autorů hlavními kritérii úroveň a míra zapojení žáků. K nejčastěji citovaným modelům tohoto typu, s nímž se setkáváme i v českých textech, patří Hartův (1997) osmistupňový žebříček participace žáků. Jednou z přijímaných alternativ Hartova modelu je model Tresedera (1997), který podobně jako Hart použil koncept participace iniciované žáky a dospělými.

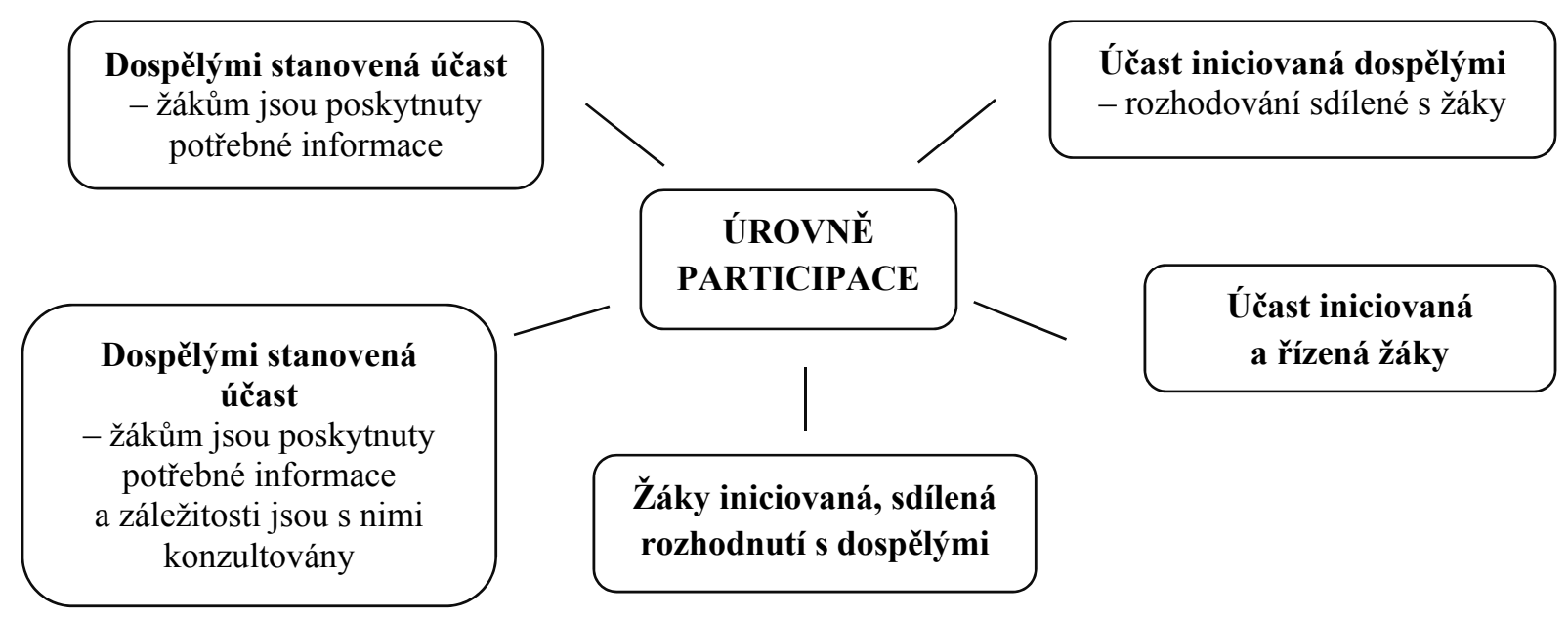

Obrázek 1. Úrovně participace žáků. Převzato z Treseder (1997).

Tresederův (1997) model naznačuje, že je možné diferencovat mezi jednotlivými způsoby účasti a zapojení žáků v souvislosti s jejich aktuálními přáními a požadavky, s ohledem na možnosti školy, čas apod. Především z tohoto důvodu Treseder zvolil na rozdíl od Harta (1997) kruhový model (nehierar- 
chický osmistupňový „žebříček“2), v němž použil shodná označení pro jednotlivé úrovně participace jako Hart. Jak je patrné z modelu na obrázku 1., Treseder ve svém modelu nepočítá s osmi úrovněmi, ale pouze s pěti, nebot' vynechává ty, které Hart nepovažuje za skutečnou participaci ${ }^{3}$. Podle Tresedera je důležité posilovat participaci žáků především podporou a vytvořením podmínek ze strany učitelů a vedení školy.

V posledních letech někteří zahraniční autoři přicházejí s novými modely, v nichž kladou důraz více na to, zda dospělí naslouchají žákům a jejich hlasy při vzájemné spolupráci a spolurozhodování zohledňují. V zahraniční literatuře ${ }^{4}$ se nejčastěji setkáváme s odkazy na model Holdswortha (2000), Mitrové (2007), nebo Fieldinga (2001) ${ }^{5}$.

První, Holdsworthův (2000, s. 358) žebříček participace žáků/mladých lidí, tvoří šest na sebe navazujících stupňů:

(1) mluvit nahlas $\rightarrow$ (2) být slyšen $\rightarrow$ (3) být poslouchán $\rightarrow$ (4) být poslouchán vážně a s respektem $\rightarrow$ (5) pohled žáků je zahrnut do uskutečňovaných činnosti $\rightarrow$ (6) sdílené rozhodování, jeho uskutečnění a jeho reflexe žáky.

Jinou typologii nabízí na základě svých zkušeností s výzkumem Mitrová (2007, s. 727-728), která rozlišuje tři úrovně:

(1) naslouchání, jako proces, při němž dospělí ve škole naslouchají sdělením žáků jako formě hrubé informace, která je základem pro výzkum nebo reformu;

(2) spolupráci, při níž žáci a učitelé společně hledají možnosti potenciálních změn ve třídě a škole ${ }^{6}$. Rozhodnutí jsou sdílená, ale nejčastěji jsou dospělí těmi, kdo má poslední slovo;

2 Podle některých autorů má Hartův „žebříček“ participace jisté limity pro svoji hierarchičnost, nebot' participaci, popsané na spodních př́ičkách žebříčku, je připisována nižší hodnota než $\mathrm{v}$ případě horních příček. Tito autoři argumentují zejména tím, že pokud má žák možnost volby, zda se bude či nebude něčeho účastnit, už v té chvíli lze mluvit o participaci (srov. Treseder, 1997).

3 Těmito úrovněmi jsou: (1) Manipulativní účast; (2) Dekorativní účast; (3) Formální účast.

4 Představené modely jsou čerpány $\mathrm{z}$ monografií a vědeckých článků publikovaných významnými anglosaskými a americkými odborníky zabývajícími se tématem participace žáků v letech 2000-2011.

$5 \quad$ Z dalších modelů bývají v zahraniční odborné literatuře citovány např. model Lodgeové (2005) a Thompsona a Guntherové (2006).

6 Mitrová (2007) o této spolupráci píše jako o společném výzkumu učitelů a žáků. 
(3) vedení, představující aktivní účast a současně zodpovědnost žáků v procesech změn ve škole, dospělí poskytují žákům podporu.

Z popsaného je zřejmé, že Mitrová (2007) naslouchání chápe jako základ pro reálné uplatnění hlasu žáků, přičemž spolupráce a vedení signalizují rostoucí roli a vliv žáků ve škole.

V současnosti je snad nejčastěji citován Fieldingův (2001) model, v němž naslouchání hlasu žáků dospělými reprezentuje čtyři odlišné významy, založené na čtyřech rozdílných rolích žákủ a účelech naslouchání. Rozlišujícím kritériem je zde vliv žáka jeho vztah k činnosti:

(1) žáci jako zdroje dat (data source) - učitelé věnují pozornost hlasu žáků $\mathrm{v}$ průběhu školního dne s vědomím, že informace získané od žáků mohou přispět $\mathrm{k}$ podpoře procesů vyučování a učení. Tyto informace učitelé využívají také ke zlepšení své výuky;

(2) žáci jako aktivní respondenti (active respondents) - předpokládá ochotu učitelů cíleně naslouchat tomu, co žáci říkají o svých zkušenostech ze života tř́dy a školy;

(3) žáci jako spolu-výzkumníci (co-researchers) - předpokládá větší partnerství učitelů a žáků než ve dvou předchozích úrovních. Žáci přestávají být jen diskutujícími, ale jsou zapojováni do řešení otázek považovaných obecně za důležité. Hranice toho, co a do jaké míry bude řešeno, určuje učitel, avšak přispění a souhlas žáků zde hraje významnou roli. Diskuze je zde nahrazena učitelem vedeným dialogem, který se projevuje zvýšenou pozorností naslouchání hlasu žáků;

(4) žáci jako výzkumníci (researchers) - partnerství učitele a žáků představuje hlavní pracovní motiv. Žáci jsou těmi, kdo identifikuje, které otázky školního života mají být řešeny nebo zkoumány a současně jsou zodpovědní za získaná data, sepsání zprávy i prezentaci zjištění. Učitelé poskytují žákům aktivní podporu, přičemž vzájemná diskuze (vedená spíše žáky než učiteli) je jádrem tohoto modu.

Z přehledu vybraných modelů je zřejmé, že jejich autoři pracují s různými pojetími naslouchání žákům: naslouchání jako cesta ke změně dospělými ř́zené školní praxe; naslouchání vedené myšlenkami žáků o tom, co je potřeba změnit. 


\section{Hlas žáků jako součást jejich participace na životě školy}

$\mathrm{V}$ posledních letech je $\mathrm{v}$ zahraničí hojně používáno $\mathrm{v}$ různých kontextech metaforické slovní spojení pupil/student voice/s, což lze v češtině vyjádřit jako hlas/y žáků/studentů. Nejčastěji se toto spojení objevuje $\mathrm{v}$ textech zabývajících se tématem participace žáků na životě školy nebo v obecnější rovině v souvislosti s rozvojem a proměnou současné školy. Jedná se o koncept používaný ve vzrůstající míře od počátku devadesátých let minulého století, ale lze se s ním setkat i v textech z let sedmdesátých. ${ }^{7}$

Definování i praktické používání konceptu označovaného jako hlas žáků je od počátku jeho vzniku až do současnosti komplikováno především šíŕí aktivit pod něj zahrnovaných. Tento fakt velmi znesnadňuje snahy vymezit hlas žáků vůči v zahraničí současně užívaným pojmům konzultování a participace žáků. V textech zahraničních autorů se setkáváme s následujícími třemi základními pojetími ${ }^{8}$, ve kterých hlas žáků bývá autory používán jako:

(1) synonymum k pojmu participace žáků na životě školy - hlasem žáků jsou myšleny takové aktivity, při nichž se žáci aktivně účastní života školy a podílejí se na jeho utváření;

(2) součást pojmu konzultování - konzultování vychází z aktivního zájmu dospělých o pohled žáků na školní procesy a je chápáno jako součást širšího konceptu participace žáků;

(3) samostatný koncept - hlas žáků je samostatným konceptem, který není ztotožňován s konzultováním ani s participací žáků; iniciativa a aktivita sdělovat svůj pohled na školní procesy vychází v tomto pojetí od samotných žáků, nikoli od dospělých, jako je tomu v př́ípadě konzultování. $V$ tomto pojetí hlas žáků může, ale nemusí vést $\mathrm{k}$ participaci žáků na záležitostech, $\mathrm{k}$ nimž se vyjadřují. Hlas žáků zde představuje podřazený pojem k participaci žáků.

První skupinu reprezentuje např́́klad definice Rogerse (2005), podle něhož hlas žáků představuje možnost žáků vyjádřit své názory a činit rozhodnutí vztahující se k plánování, průběhu a evaluaci svého učení. Podobně jako Rogers vztahuje hlas žáků k jejich participaci na vyučování a učení také

7 Vývoji terminologie a proměnám v chápání obsahu konceptu hlas žáků se podrobněji věnujeme v jiném textu (Vidláková, 2011).

8 Rozdělení vychází ze studia monografií a vědeckých článků významných anglosaských a amerických autorů zabývajících se tématem participace žáků v letech 2000-2011. 
Harper (2000). V Harperově vymezení hlas žáků představuje vliv žáků na průběh vyučování a učení, jmenovitě jeho koncepci, program, kontexty a principy. Širší definici nabízí Cook-Satherová (2006), podle níž v sobě slovo hlas zahrnuje pojmy moc a vliv. Jimi v souvislosti se školním vzděláváním autorka rozumí především možnosti žáků vyjádřit, co si myslí, být vyslyšeni a oceněni dospělými za vyjádření svých názorů. Je-li to možné, měli by mít žáci současně vliv na výsledné řešení záležitostí, k nimž se vyjadřují. Hlas žáků v pojetí Cook-Satherové (2006) tedy představuje prostředek, jímž o sobě žáci dávají vědět, pojmenovávají svoji zkušenost a participují na rozhodnutích ovlivňujících jejich život.

Do druhé skupiny lze zařadit vymezení používané týmem výzkumníků z Univerzity v Cambridge. Podle nich pojem hlas žáků odkazuje na aktivní participaci žáků na procesech svého učení prostřednictvím jeho konzultování $i^{9}$ s učiteli. Autoři Rudducková a McIntyre (2007) konzultování popisují jako proces, kdy učitelé mluví s žáky o záležitostech třídy a školy majících vliv na jejich učení. $V$ ideálním př́ípadě konzultování iniciované učiteli směřuje k oboustranné a plynulé diskuzi žáků a učitelů o učení. Žáci by měli být učiteli podněcováni $\mathrm{k}$ vyjadřování svých zkušeností $\mathrm{s}$ výukou, například co jim učení usnadňuje, co je $\mathrm{v}$ učení podporuje a co je naopak matoucí nebo obtížné. Konzultování by podle Rudduckové a McIntyra (2007) mělo vycházet $\mathrm{z}$ explicitního zájmu dospělých o pohled žáků na výukový proces. Současně žáci, s nimiž je konzultováno, by měli vědět, že jejich názory učitelé skutečně chtějí znát, protože očekávají, že žáci mohou v diskusi přispět něčím užitečným.

Podobné vymezení nalezneme u například u Mitrové (2007). Zájem učitelů o hlasy žáků má podle této autorky vycházet zejména z přesvědčení, že žáci mají jedinečný pohled na školu a život v ní, který učitelé nemohou plně postihnout.

Do poslednískupiny definic spadá např́iklad definice Robertse a Nashe (2006), kteří hlas žáků popisují jako individuální či kolektivní iniciativy, při nichž žáci mohou vyjádřit své názory k záležitostem školního života s očekáváním, že jim budou učitelé naslouchat. Podobně hlas žáků definují i členové významné

Podobně jako spojení hlas žáků se ani koncept konzultování (nebo jiný koncept označující totéž) v české pedagogice neobjevuje v kontextu participace žáků na životě školy. Dủvod lze spatřovat $\mathrm{v}$ nedostatečné hloubce zpracování tématu na úrovni teorie i výzkumu (viz další text). 
americké organizace podporující výzkum zaměřený na aktivní účast žáků na životě školy s názvem Sound out. Na rozdíl od Robertse a Nashe (2006) ale tým členů zmíněné organizace definuje kromě hlasu žáků současně i pojmy zapojení, konzultování a participace, z nichž je patrný rozdíl, který spatřují mezi těmito koncepty. Hlasem žáků autoři rozumí individuální a kolektivní iniciativy a aktivity žáků, při nichž žáci vyjadřují svůj pohled na záležitosti školního života (Fletcher, 2007). Fletcher dále uvádí, že hlas žáků by neměl být ztotožňován se zapojením žáků (involvement), tedy s obecným procesem směřujícím k podpoře žáků jako partnerů pro rozvoj školy, konzultováním (consultation), systematickým procesem, $\mathrm{v}$ němž učitelé naslouchají názorům žáků vztahujícím se ke škole ani s participací žáků (participation), tedy podílem na rozhodování. Hlas žáků k těmto procesům může, ale nemusí vést. Dospělí ve škole by měli usilovat o to, aby žáci participovali na rozhodování o záležitostech, k nimž se sami vyjadřují.

Při porovnání popsaných tř́ způsobů vymezování hlasu žáků se jako významné jeví rozdíly $v$ iniciativě a aktivitě žákủ. $\mathrm{V}$ poslední skupině definic je hlas žáků spojován výhradně s iniciativou ze strany žáků, autoři se tak zaměřují na zjištování iniciativ a aktivit vycházejících od samotných žáků bez konkrétního impulzu ze strany dospělých. Jinými slovy, pokud nám jde o hlas žáků, měli bychom se podle těchto autorů zajímat o to, s jakými záležitostmi a podněty za dospělými ve škole žáci sami přicházejí. Naproti tomu první a druhá skupina definic vychází z předpokladu iniciativy dospělých ve škole, kteří se budou aktivně a cíleně zajímat o pohled žáků.

Z představených tří způsobů definování hlasu žáků se jako nejvhodnější jeví poslední způsob, v němž je hlas žákủ vymezován jako samostatný pojem, který je součástí širšího konceptu participace žáků. Vyjádření žáků k některé z oblastí školního života totiž přímo neimplikuje jejich podíl na sdíleném rozhodování s dospělými o této oblasti. Především z tohoto důvodu by hlas žáků neměl být používán jako synonymum k pojmu participace žáků, což se v zahraniční literatuře objevuje nejčastěji.

Hlas žáků lze v tomto pojetí vymezit jako komunikační iniciativy žáků, při nichž se žáci vyjadřují k různým záležitostem školního života s očekáváním, že jim dospělí ve škole budou naslouchat a reagovat na jejich sdělení. Tyto iniciativy vycházejí od žáků a mohou být individuální nebo kolektivní.

Z tohoto vymezení vyplývá, že komunikační iniciativy žáků jsou vždy cílené, nebot' se s nimi pojí konkrétní očekávání žáků (dospělí budou žákům 
naslouchat a reagovat na jejich sdělení). Vyjádření žáků mohou být přitom nejen pečlivě připravovaná, ale i spontánní. Hlas žáků současně představuje něco hlubšího, než jen běžnou komunikaci ve výuce. Jde zde o konkrétní otázky školního života, které jsou podstatné pro žáky (MacBeath, 2005). Komunikačními iniciativami zde rozumíme verbální projevy žáků, které mohou být ústní nebo i písemné (např v podobě petice adresované řediteli školy nebo podnětu vloženého do tzv. schránky důvěry).

V souvislosti s pokusy vymezit co je a není hlas žáků, je na místě také objasnit, co reprezentuje slovo „hlas“. Pokud se zahraniční autoři ve svých textech zabývají úvahami nad slovem hlas (voice), odkazují shodně na Britzmanovu definici hlasu (srov. Cook-Sather, 2006; Silva, 2001). V Britzmanově (1989) pojetí pojem hlas zasahuje oblast jazyka, metafory a politiky. $V$ oblasti jazyka podle Britzmana hlas představuje řeč a perspektivu mluvčího; $v$ oblasti metafory v sobě hlas zahrnuje načasování, tón, akcent, styl a také vlastnosti a pocity sdělované mluvčím; politicky pojem hlas odkazuje k právu vyjádřit se a prezentovat se. Spojení hlas žáků má tedy podle citovaných autorů odkazovat k jednotlivým dimenzím, o nichž je třeba uvažovat v souvislosti s tím, co žáci učitelům sdělují.

Někteří autoři ale se spojením „hlas žáků“ nesouhlasí a upozorňují na to, že toto spojení má tendenci odkazovat $\mathrm{k}$ jednomu monolitickému hlasu žáků (srov. Lodge, 2005). Spojení hlas žáků v nás totiž může vyvolávat mylnou představu, že existuje jakýsi uniformní hlas žáků. MacBeath et al. (2006) přímo píší, že užívání pojmu hlas považují v souvislosti s žáky za nevhodné, nebot' se vystavujeme nebezpečí přehlédnutí podstatných rozdílů mezi žáky, jejich pohledy a potřebami.

Podle Silvové (2001) se při používání spojení „hlas žáků“ vystavujeme také nebezpečí popření potenciálu mlčení a resistence žáků. Mlčení může znamenat, že žáci nechtějí vyjadřovat své názory, protože to považují za bezvýznamné, nebo mají obavu z reakce dospělých ve škole. Může se rovněž jednat o záměrně zvolenou strategii žáků vůči jejich učitelům jako následek předchozích pokusů, kdy nebyli vyslyšeni.

Navzdory těmto výtkám považujeme za vhodné používat spojení hlas žáků, a to i v českém kontextu, nebot' lze jen obtížně nalézt jiné vhodnější slovo či sousloví, které by pokrylo jednotlivé dimenze, jež v sobě zahrnuje slovo hlas. 
Jakje naznačeno jižv úvodu textu, hlas žáků je konstruktem, kterýv současném českém pedagogickém diskurzu zatím nemá své místo. $V$ českém prostředí autoři se spojením „hlas žákü“ samostatně zatím nepracují ani jej nevymezují. Pokud jde o přičiny neužívání spojení hlas žáků u nás (nebo jiného pojmu označujícího totéž ${ }^{10}$, hlavní důvod lze spatřovat $v$ malém zájmu českých odborníků o teorii a výzkum vztahující se k celé oblasti participace žáků, a tudíž i v absenci širší odborné diskuze k tématu. Obecný zájem o to, co lze označit jako „hlas žákư", je u nás implicitní ve školských dokumentech (Národní program..., 2001; Rámcový vzdělávací program..., 2005). Pokud jde ale o empirické poznatky vztahující se k iniciativám samotných žáků, které by měly být významnou součástí jejich participace na chodu školy, nabízí jich český pedagogický výzkum jen poskrovnu. Současné, málo početné a navíc často polytematické výzkumy ukazují, že reálná podpora směřující k tomu, aby se žáci sami aktivně vyjadřovali ke školním procesům a participovali na nich, u nás není systematická - nejen vůči žákům, ale ani vůči učitelům, kteří by žákům měli aktivně naslouchat a s jejich podněty pracovat (např. Kř́žová et al., 2001; Mladé hlasy..., 2008; Rychlá šetření..., 2010; Soukup, 2010). $\mathrm{V}$ těchto výzkumech navíc absentuje specifikace, o jaký typ iniciativ žáků se jedná, co autoři vlastně považují za iniciativy žáků, $k$ jakým konkrétním oblastem školního života se iniciativy českých žáků vztahují a následně, vjakých oblastech se vliv žáků reálně uplatňuje.

Pokud jde o stav teorie vztahující se k participaci žáků, je u českých autorů patrná tendence věnovat se spíše obecnějším tématům. 0 participaci žáků se u nás nejčastěji píše ve spojení s výchovou k demokracii a občanství (Kaplánek \& Kočerová, 2011), zákonnými právy žáků (Hofbauer, 2003), žákovskou samosprávou (Klapal \& Prášilová, 2002; Staněk, 2009; Šturma \& Janiš, 1999) a demokracií ve škole (Pol, Rabušicová, \& Novotný, 2006). Dalšímu možnému pohledu na participaci žáků se věnuje Bendl (2005), který o ní píše ve spojení s kázní ve škole. Otázek participace žáků se okrajově dotkli autoři víceprŕípadové studie české základní školy (Dvořák et al., 2010),

10 V literatuře se setkáváme se spojeními, jako například názory žáků či pohled žáků na záležitosti školního života, iniciativy a aktivity žáků (srov. Dvořák et al., 2010; Rychlá..., 2010; Soukup, 2010). Autoři však nerozlišují, zda se jedná o sdělení iniciovaná samotnými žáky (hlas žáků) nebo o sdělení žáků vycházející z aktivního zájmu dospělých o pohled žákủ na školní procesy (koncept konzultování). Zjištění dále nejsou vztahována k participaci žáků na životě školy a neposkytují tak odpověd' na otázku, zda žáci reálně participují také na oblastech, k nimž se sami vyjadřují. Především v tomto ohledu je vzájemné rozlišení konceptů hlas žáků a konzultování přínosné pro úvahy o participaci žáků. 
studie Pražské skupiny školní etnografie (2001) nebo výzkum kultury školy Hlouškové (2008). Také ve vztahu k řízení, fungování a rozvoji školy se participace žáků nestala od r. 1989 předmětem komplexnějšího teoretického zpracování ani empirického zkoumání (Redlichová, 2006).

Participace žáků na konkrétních oblastech školního života, její možné podoby a podmínky pro její uplatnění nejsou příliš popsány v naší odborné pedagogické literatuře. Například participaci žáků ve vyučování, která by měla být z hlediska cílů školního vzdělávání klíčovou, je u nás v pedagogické teorii věnována jen malá pozornost. Stejně tak je opomíjeno zodpovězení obecnější otázky: Jak se má participace žáků reálně uskutečňovat? (Novotná, 2008). A dále: Jakou roli by v tomto procesu měl sehrávat hlas žáků? Chybí rovněž propracované evaluační nástroje, jimiž by participace českých žáků mohla být hodnocena.

\section{Vybrané problémy spojené s uplatňováním hlasu žáků}

Myšlenky naslouchat žákům jsou mnohými výzkumníky i učiteli přijímány, zatímco jinými jsou naopak označovány za „Pandořinu skř́ńnu“. Snahy naslouchat žákům a umožňovat jim spolurozhodovat v záležitostech, které se jich týkají, mohou kromě pozitiv způsobovat ve škole i tenze, nejen mezi dospělými, ale i mezi učiteli a žáky. Učitelé i žáci mohou mít například obavy, že jejich aktivita ovlivní jejich vztahy s ostatními žáky a učiteli, jejich hodnocení apod. Zajímavé v této souvislosti je, že v současné zahraniční literatuře se v hojné míře dočteme převážně jen o pozitivech týkajících se hlasu žáků. Zmínění či diskuze problémů spojených s celým konceptem se naproti tomu v literatuře objevuje jen velmi zř́dka. Zejména prakticky orientované publikace a manuály pro učitele jen málo diskutují o problémech spojených s hlasem žáků a obecně i s participací žáků (Fielding \& Bragg, 2003; Fajerman \& Treseder, 2004; MacBeath et al., 2003).

V následujících řádcích se budeme zamýšlet nad základními otázkami, jimž je př́ihodné $v$ souvislosti s uplatňováním hlasu žáků věnovat pozornost ${ }^{11}$. Jak poukazuje MacBeath (2005), hlasu žáků můžeme porozumět jen v komplexu přesvědčení, vztahů, konvencí a struktur, které charakterizují to, co bývá dnes označováno jako kultura školy. Nebezpečí nakládání s hlasy žáků tak

11 S ohledem na to, že hlas žáků je v textu pojímán jako součást jejich participace na životě školy, popsané problémy se týkají nejen uplatnění hlasu žáků, ale v obecnější rovině i celé oblasti zastřešované pojmem participace žáků. 
spočívá především v tom, že dospělí na ně nemusejí vždy nahlížet v širším kontextu života školy a existujících struktur. Za nejproblematičtější oblasti spojené s uplatňováním hlasu žáků jsou v tomto kontextu obecně považovány komunikace, naplňování demokratických principů školní práce a mocenské vztahy učitelů a žáků (srov. Robinson \& Taylor, 2007).

$\mathrm{V}$ oblasti komunikace je třeba věnovat pozornost obsahu sdělení žáků. Konkrétně: Čeho se hlasy žáků týkají? K jakým záležitostem a v jaké míre by měli žáci mít možnost se vyjadřovat a participovat na nich? Jaké jsou hranice, kam až žáci mohou zajít? Jak kritičtí žáci mohou být? Pro smysluplnost participace žáků v prostředí školy je důležité, aby se hlasy žáků týkaly co nejvíce toho, co je ve škole klíčové, tedy vyučování a učení. Opomíjet bychom však neměli ani hlasy žáků k dalším oblastem školního života, nebot' současné výzkumy naznačují, že tyto procesy nelze zcela izolovat od ostatních oblastí života školy, které spoluutvářejí pohled žáků na jejich školu a ovlivňují hlas žáků (srov. Flutter, 2006; Burke \& Grosvenor, 2003). Současně je třeba hledat rovnováhu mezi tím, jak následnou participaci žáků udržet pod kontrolou a přitom ji nesvazovat.

Zamýšlet se musíme také nad rovným přístupem k žákủm, který kromě oblasti komunikace zasahuje i oblast demokracie. Zde se nabízejí otázky: Č́ hlasy promlouvají a komu naslouchat? Zda dobrovolníkưm, kteří se přihlásí, nebo snad těm, kdo mají dobré/špatné výsledky? Pokud možno by to neměly být hlasy jen některých žáků a současně by to neměli být jen někteři žáci, kdo se bude moci vyjadřovat a participovat na životě školy. Zapomínat bychom neměli ani na mnohdy mlčící žáky z různých sociálních a etnických prostředí. Silvová (2001) v závěru svého výzkumu uvádí, že více informací podnětných pro podporu výukového procesu se učitelé dověděli od těch žáků, kteří měli ve škole problémy, než od premiantů. Při uplatňování hlasu žáků je nutné rovněž hledat rovnováhu mezi individuálními a kolektivními sděleními žáků, která jsou nezřídka rozdílná.

Kdo hlasům žáků naslouchá? To je další podstatná otázka. Pro to, aby se hlasy žáků mohly stát skutečným nástrojem změn ve škole, je důležité, aby žákům nenaslouchalo jen několik málo učitelů, ale aby se tyto hlasy dostávaly až $\mathrm{k}$ těm, kdo o věcech rozhodují. S tím souvisí i otázka: Co se děje s hlasy žáků? Dostávají žáci od učitelu a vedení školy zpětnou vazbu, jaká je tato zpětná vazba - směřuje $k$ rozvoji školy, její efektivitě, učení se žáků, demokracii...? Pozornost je vhodné věnovat i tomu Jak rozumíme hlasưm žáků? Interpretace cizích projevů obecně není jednoduchá, v souvislosti s hlasy žáků je navíc 
komplikována rozdílnou úrovní vyspělosti a generačními rozdíly mezi jednotlivými aktéry školního života.

Problematická je rovněž iniciativa žáků. Jak nejúčinněji žáky aktivizovat, aby za učiteli sami přicházeli, vyjadřovali svůj pohled na školní procesy a následně na nich také participovali? Ve výsledcích výzkumů z poslední doby se opakovaně ukazuje, že bez podpory ze strany učitelů často žádnou iniciativu sami neprojeví (Fielding, 2004a; Mitra, 2006; Vidláková, 2011).

Jak uvádí Mitrová (2007), v souvislosti s uplatňováním hlasu žáků bychom měli také uvažovat nad tím, jakou váhu by měl mít hlas žáků? Odpověd' na tuto otázku je spojená se zodpovězením obecnější otázky: Kdo by měl definovat, jaké jsou problémy současného školství a kdo by se měl pokoušet je napravit? Podle Braggové (2001) v sobě uplatnění hlasu žáků zahrnuje rovněž výzvy, kterým někteří dospělí nebudou ochotni čelit. Braggová konkrétně uvádí, že problematické se jeví zejména naslouchání učitelů takovým sdělením žáků, která vlastně ani př́liš slyšet nechtějí. Komentáře žáků k práci jejich učitelů mohou být někdy velmi kritické a ne všichni učitelé budou schopní je přijmout jako podněty pro změnu své práce. $S$ tím souvisí také obtížnost učení se z něčeho, co učitelé nechtějí př́liš slyšet.

Někteří autoři (Cook-Satherová, 2006; Fielding, 2004b; Robinson \& Taylor, 2007) poukazují na to, že uplatnění hlasu žáků do velké míry závisí na existujících mocenských vztazích učitelů a žáků, nebot ty významně ovlivňují komunikační procesy ve škole. Změnu vztahů mezi učiteli a žáky proto tito autoři považují za jeden $\mathrm{z}$ klíčových předpokladů i výsledků snah o větší zapojení žáků do školních procesů. Jak dokládají některé studie, možné změny ve vztazích učitelů a žákư jsou ale považovány zejména dospělými ve škole za problematické a jsou spojené s obavami učitelů ze ztráty autority (Rudduck \& McIntyre, 2007).

Na další možný problém spojený s uplatnění hlasu žáků upozorňuje Silvová (2001). Podle této autorky může zvýšený zájem o hlasy žáků a jejich participaci na životě školy vést v krajních případech až k privilegování žáků ve vztazích s dospělými ve škole. To samo o sobě by podle autorky způsobilo spíše narušení reformních snah než jejich uskutečňování.

Fineová etal. (2007) rozvíjí myšlenku nebezpečí příliš romantického nahlížení na žáky, kdy mohou být dospělí reflektováni jako ochránci žáků mající nad nimi patronát. Autoři konstatují, že př́lišné apelování k naslouchání hlasu 
žáků může vést $\mathrm{k}$ tomu, že žáci budou vyslyšeni, ale reálně jejich role, pokud jde o změny ve školním vzdělávání, bude spíše dekorativní.

Zcela odlišný pohled na uplatnění hlasu žáků přináší Giroux (2005, s. 282). Na rozdíl od většiny autorů, kteří žáky staví do role nevyslyšených „obětí školského systému", jsou žáci podle Girouxe naopak těmi, kdo neustále zkouší aktivně vzdorovat učitelům a usiluje o „neučení se“. S tím bychom měli podle autora při uplatňování hlasu žákủ také počítat.

Kromě problémů spojených s uplatněním hlasu žáků je třeba uvažovat i o problémech spojených s tím, jak je dospělými nakládáno se sděleními žáků? Silvová a Rubin (2003) zmiňují zejména nebezpečí př́lišného zjednodušování toho, o čem žáci hovoří. Budeme-li se upínat pouze na to, co zajímá nás, nebo co bychom chtěli slyšet my, povede to pouze $\mathrm{k}$ symbolickému zájmu o hlas žáků (tokenism), manipulaci a takovým aktivitám žáků, při nichž se nenaplní cíle spojované s tímto konceptem. Autoři dále doplňují, že pro výzkumníky i učitele ve školách je velmi obtížné nesklouznout k redukci hlasu žáků ,jako jedné, uniformní a neměnné zkušenosti“ (Silva \& Rubin, 2003, s. 2).

Snahy naslouchat hlasům žáků a podporovat jejich participaci na životě školy jsou v praxi často také svázány s existující organizační strukturou ve škole a školskými dokumenty. Jasně vymezené a definované kompetence a povinnosti dospělých ve škole tak leckdy neposkytují prostor pro hlasy žáků ani pro sdílené rozhodování s žáky. Výzvou pro každou školu tedy také zůstává, jak v rámci stávajících norem určujících běžné školní uspořádání vytvořit prostor pro naslouchání a uplatnění hlasu žáků.

\section{Závěrem}

Na popsaných změnách v uvažování o participaci žáků je zajímavá především skutečnost, že zájem o hlasy žáků vychází téměř výhradně $\mathrm{z}$ vnějšku, od výzkumníků, nikoli od škol samotných (Fielding, 2004a). Ukazuje se současně, že výzkumníci se ve svých textech více věnují prezentaci výsledků empirických výzkumů, zatímco rozvoj teorie zůstává v pozadí (srov. Robinson \& Taylor, 2007). Existující výsledky jejich studií ve své většině také teprve čekají na své uplatnění v praxi, přestože se v zahraničí už od poloviny 90 . let píše o hlasu žáků jako o legitimní součásti uvažování o vzdělávací politice.

Současný stav teorie a výzkumu v oblasti participace žáků v České republice zatím neodráží naznačené změny, které se v zahraničí v posledních letech 
projevily zvýšeným zájmem výzkumníků o hlasy žáků k různým oblastem školního života (Vidláková, 2011). Nezodpovězené zůstávají rovněž mnohé konkrétní otázky týkající se participace žáků jako například: Jak a kým je $v$ českých školách iniciována participace žákủ? Jaké oblasti považují jednotlivé skupiny lidí ve škole (ředitelé, učitelé, žáci) za klíčové pro participaci žáků $\checkmark$ porovnání s teoretickými koncepty? Jaké formy participace žáků preferují jednotlivé skupiny lidí ve škole? Jaký význam připisují participaci žákủ ředitelé škol, učitelé a samotní žáci? Jaké jsou vize jednotlivých skupin lidí o podobě $a$ výsledcích participace žáků $v$ porovnání s realitou? A také: Jak se v celém procesu participace žáků uplatňují vlastní iniciativy žáků ( $v$ zahraničí označované jako hlas žákủ)? Otázkou rovněž zůstává, zda se spojení „hlas žákü“ (nebo jiné označení pro tento koncept) stane součástí i českého pedagogického diskurzu.

Teoretické i empirické uchopení těchto otázek, jimiž se budeme dále zabývat, považujeme za klíčové nejen z hlediska odborného rozvoje tématu, ale i z hlediska možné aplikace získaných výsledků ve školní praxi a učitelské přípravě.

\section{Literatura}

Bendl, S. (2005). Žáci, škola a společnost: reinterpretace kázně v současné škole. Pedagogická orientace, 15(2), 2-8.

Bílá kniha Evropské komise - Nový podnět pro evropskou mládež. (2002). Komise Evropských společenství. Praha: MŠMT.

Bragg, S. (2001). Taking a joke: Learning from the voices we don't want to hear. Forum, 43(2), $70-73$.

Britzman, D. (1989). "Who has the floor? Curriculum teaching and the English student teacher's struggle for voice". Curriculum Inquiry, 19(2), 143-162.

Burke, C., \& Grosvenor, I. (2003). The school I'd like: Children and young people's reflections on an education for the $21^{\text {st }}$ century. London: Routledge Falmer.

Cook-Sather, A. (2006). Sound, presence, and power: „Student voice“ in educational research and reform. Curriculum Inquiry, 34(4), 359-390.

Dvořák, D., Starý, K., Urbánek, P., Chvál, M., \& Walterová, E. (2010). Česká základní škola. Vícepř́ípadová studie. Praha: Karolinum.

Giroux, H. A. (2005). Literacy and the pedagogy of voice and political empowerment. Educational Theory, 38(1), 61-75.

Efektivní učení ve škole. (2005). Praha: Portál.

Fajerman, I., \& Treseder, P. (2004). Empowering children and young people. London: Save the Children.

Fielding, M., \& Bagg, S. (2003). Students as reseachers: Making a difference. Cambridge: Pearson Publishing. 
Fielding, M. (2001). Students as radical agents of change. Journal of Educational Change, 2(3), 123-141.

Fielding, M. (2004). "New wave" student voice and the renewal of civic society. London Review of Education, 2(3), 197-216.

Fielding, M. (2004a). Transformative approaches to student voice: theoretical underpinnings, recalcitrant realities. British Educational Research Journal, 30(2), 295-311.

Fine, M., Torre, M. E., Burns, A., \& Payne, Y. A. (2007). Youth research/participatory methods for reform. In D. Thiessen \& A. Cook-Sather (Eds.), International handbook of student experience in elementary and secondary school (s. 805-528). Dordrecht: Springer.

Fletcher, A. (2007). Student voice tip sheet. Dostupné z http://www.soundout.org/tips.html.

Flutter, J., \& Rudduck, J. (2004). Consulting pupils: What is in it for schools? London: Routledge Falmer.

Flutter, J. (2006). This place could help you learn: Student participation in creating better school environments. Educational Review, 58(2), 183-193.

Harper, D. (2000). Students as change agents: The generation Y model. Olympia, WA: Generation Y. Dostupné z http://www.soundout.org/definition.html.

Hart, R. (1997). Children's participation: The theory and practice of involving young citizens in community development and environmental care. London: Earthscan.

Hloušková, L. (2008). Proměna kultury školy v pedagogických diskurzech. Brno: Masarykova univerzita.

Hofbauer, B. (2003). Participace dětí a mládeže na životě společnosti: Evropské struktury a jejich aktivity. Praha: Duha, IZV Hořovice \& MŠMT ČR.

Holdsworth, R. (2000). Schools that create real roles of value for young people. Prospect, 30(3), 349-362.

Kaplánek, M., \& Kočerová, M. (2011). Participace - nejlepší způsob výchovy k demokracii. e-Pedagogium, 11(1), 18-37.

Klapal, V., \& Prášilová, M. (Eds.). (2002). Aktuální problémy žákovské samosprávy. Sborník z pracovního semináře. Olomouc: Katedra pedagogiky s celoškolskou působností PdF UP.

Koncepce státní politiky pro oblast dětí a mládeže do roku 2007. (2003). Praha: MŠMT.

Křižová, I. et al. (2001). Znalosti, dovednosti a postoje čtrnáctiletých žáků v oblasti občanské výchovy. Praha: ÚIV.

Lodge, C. (2005). From hearing voices to engaging in dialogue: Problematizing student participation in school improvement. Journal of Educational Change, 6(2), 125-146.

MacBeath, J. (2005). A chain of voices. Dostupné z http://www.sst-inet.net/olc/paperdetails. aspx?id=1\&pid=1\&opt=paper\#

MacBeath, J., Demetriou, H., Rudduck, J., \& Myers, K. (2003). Consulting pupils: A toolkit for teachers. Cambridge: Pearson.

MacBeath, J., Schratz, M., Meuret, D., \& Jakobsen, L. (2006). Serena aneb autoevaluace škol v Evropě. Ždár n. Sázavou: Fakta.

Mitra, D. L. (2006). Educational change on the inside and outside: The positioning of challengers. International Journal of Leadership Education, 9(4), 315-328.

Mitra, D. L. (2007). Student voice in school reform: From listening to leadership. In D. Thiessen, \& A. Cook-Sather (Eds.), International handbook of student experience in elementary and secondary school (s. 727-744). Dordrecht: Springer. 
Mladé hlasy: Závěrečná zpráva. (2008). Dostupné z http://www.vyzkum-mladez.cz/zpravy/ 1225714651.pdf

Národní program rozvoje vzdělávání v České republice. (2001). Praha: MŠMT.

Novotná, J. (2008). Participace žáků ve vyučování: úkoly a možnosti. In K. Starý (Ed.), Pedagogika ve škole (s. 129-140). Praha: Portál.

Pol, M., Rabušicová, M., \& Novotný, P. et al. (2006). Demokracie ve škole. Brno: MU.

Pražská skupina školní etnografie. Co se v mládí naučíšs. (2001). Praha: PdF UK.

Rámcový vzdělávací program pro základní vzdělávání. (2005). Praha: VÚP.

Redlichová, J. (2006). Participace žáků na životě školy: staronové téma pedagogiky. Sborník prací filozofické fakulty brněnské univerzity. Řada pedagogická (U) (s. 145-157). Brno: MU.

Revidovaná Evropská charta participace mladých lidí na místním a regionálním životě. (2004). Pedagogická orientace, 14(1), 96-109.

Roberts, A., \& Nash, J. (2006). Looking from the inside: Supporting school improvement through student-led inquiry work. Př́spěvek přednesený na Národní konferenci Pupil Voice and Participation: pleasures, promises and pitfalls, University of Nottingham, 22.-23. 6. 2006. Dostupné z http://www.pupil-voice.org.uk/Student-led-inquiryWork_ Amanda\%20Roberts_JudithNash.pdf

Robinson, C., \& Taylor, C. (2007). Theorising student voice: values and perspectives. Improving Schools, 10(1), 5-17.

Rogers, A. (2005) Student voice: Bridges to learning. Seattle: University Washington. Dostupné z http://www.soundout.org/definition.html

Rudduck, J., \& McIntyre, D. (2007). Improving learning through consulting pupils. London: Routledge.

Rychlá šetření 2/2010 - závěrečná zpráva. (2010). Praha: ÚIV. Dostupné z http://www.uiv.cz/ soubor $/ 4324$

Silva, M. E. (2001). Squeaky wheels and flat tires: A case study of students as reform participants. Forum, 43(2), 95-99.

Silva, M. E., \& Rubin, C. B. (2003). Missing Voices: Listening to students' experiences with school reform. In C. B. Rubin \& M. E. Silva (Eds.), Critical voices in school reform: Students living through change (s. 1-8). London: Routledge Falmer.

Soukup, P. (Ed.). (2010). Národní zpráva z Mezinárodní studie občanské výchovy. Praha: ÚIV. Dostupné z http://www.uiv.cz/soubor/4352

Staněk, A. (2009). Výchova $k$ občanství v současné škole: Profesní identita učitele výchovy k občanství. Praha: Nakladatelství Epocha.

Šturma, J., \& Janiš, K. (Eds.). (1999). Práva a participace dětí v rodině, ve škole a ve veřejném životě: sborník z pracovního semináře konaného 21. 4. 1999. Hradec Králové: Gaudeamus.

Thompson, P., \& Gunter, H. (2006). From 'consulting pupils' to 'pupils as researchers': A situated case narrative. British Educational Research Journal, 32(6), 839-856.

Treseder, P. (1997). Empowering children and young people: Training manual. London: Save the Children Fund.

Vidláková, J. (2011). Hlas žáků jako součást jejich participace na životě školy (Disertační práce). Dostupné z https://is.muni.cz/auth/th/40185/ff_d/Disertacni_prace_Vidlakova.pdf

Zákon č. 561/2004 Sb. o předškolním, základním, středním, vyšším odborném a jiném vzdělávání. 


\section{Autorka}

Mgr. Jitka Vidláková, Mendelova univerzita v Brně, Institut celoživotního vzdělávání, Oddělení sociální věd, Zemědělská 5, 61300 Brno, e-mail: jitka.vidlakova@mendelu.cz

\section{Changes in thinking about pupil participation: Foreign inspiration}

Abstract: The topic of the contribution is pupil participation in school life. It is a topical issue of present Czech and foreign education, which has been discussed with varying degrees of intensity in the context of changing social conditions and related changes in current schools, teaching approaches and position of pupils in these processes. The study deals with changes in thinking about pupil participation in recent years which have shown development of new models of pupil participation. The article provides an overview of those models in which their authors emphasize listening to pupil voices by adults at school. Another part of the text is devoted to presentation of three typical ways of defining the pupil voice that appear in foreign educational literature. Considerations about appropriateness of the use of the term pupil voice are also described as a part of an attempt to define it. In conclusion we offer key issues related to pupil participation in the Czech Republic. The study focuses primarily on research studies dealing with this issue but its' focus brings ideas and inspiration also for school practice.

Keywords: pupil participation in school life, pupil voice, consultation, listening, pupil

Lojová, G. \& Vlčková, K. (2011). Styly a strategie učení ve výuce cizích jazyků. Portál: Praha.

Publikace shrnuje odborné poznatky z oblasti strategií a stylů učení v kontextu výuky cizích jazyků. Text vychází ze soudobých poznatků psychologie, pedagogické psychologie a pedagogiky, přičemž zprostředkovává obohacujícíteoretická východiska didaktiky cizích jazyků. Publikace má pomoci rozvíjet dovednost tvořivě a flexibilně reagovat na každodenní proměnlivé pedagogické situace a hlouběji chápat svoji roli při rozvíjení cizojazyčné komunikační kompetence žákủ, rozvíjet jejich sebepoznání a samostatně pokračovat $\mathrm{v}$ cizojazyčném vývoji. Je rozdělena na části učební styly a učební strategie. 